\title{
ТРУДОВІ ВІДНОСИНИ ЯК ОБ'СКТ РИНКОВОГО РЕФОРМУВАННЯ ЕКОНОМІКИ
}

\section{DOI: 10.32620/cher.2018.4.11}

\begin{abstract}
Постановка проблеми. Стаття присвячена аналізу трудових відносин в контексті вартості робочої сили в ринковій економіці. Метою статті є обгрунтування доктрини вибору соціальних орієнтирів податкової політики, виходячи з сучасних вимог демократичних трансформації в Україні. Об'єктом дослідження виступають трудові відносини в ракурсі ринкового реформування економіки. Методи, щзо використані в дослідженні: методи систематизації і узагальнення методи; індукції та дедукції; міждисциплінарної аналогії. Гіпотезою дослідження стало припущення, що приведення рівня заробітної плати у відповідність до вартості робочої сили потребує суттєвого удосконалення трудових відносин, прийняття нового Трудового кодексу в контексті ринкової суб'єктивації виробничих відносин, складовою частиною якої виступають відносини з приводу послуг праці. Виклад основного матеріалу. Обгрунтовано, що ринок праці є ринком недосконалої конкуренції, з домінуючими позиціями роботодавців, через що важливу роль у регулюванні цін на послуги праці відіграє механізм колективно-договірного регулювання трудових відносин. В Україні протягом ринкових реформ заробітна плата є заниженою. Оригінальність та практичне значення дослідження. в контексті ефективного економічного розвитку, забезпечення умов якісного відтворення людського капіталу, досягнення компромісів у суспільстві потрібно докорінне удосконалення характеру трудових відносин. Це удосконалення передбачає прийняття низки законодавчих рішень. Мова йде про законодавче вирішення проблеми суб'єктивації виробничих відносин як ринкової форми розвитку економіки та вирішення питань ефективної зайнятості. Суб'єктивація виробничих відносин - це процес перетворення учасників економічної діяльності в суб'єктів сучасної ринкової економіки, які повинні бути рівними, мати права, соціальні обов'язки та механізми захисту. Висновки дослідження. В організації економічної діяльності, практиці господарської діяльності, як і в інших сферах життя соціуму має активно використовуватися концептуальні розробки позитивної та нормативної економічної теорії щодо створення партнерської моделі трудових відносин на ринковій основі. Найбільшою вадою ринкового реформування економіки України стало ігнорування на рівні законодавства висновків й сформульованих вимог економічної теорії, що стало причиною суттєвого заниження заробітної плати відносно вартості робочої сили й обумовило появу низки негативних явищ.
\end{abstract}

Ключові слова:

ринкова економіка, трудові відносини, теорія трудових відносин, робоча сила, трудовий потенціал, заробітна плата, соціальне партнерство.

\section{LABOR RELATIONSHIP AS A MARKET OBJECT REFORMING THE ECONOMY}

Formulation of the problem. The article is devoted to the analysis of labor relations in the context of the cost of labor in a market economy. The aim of the research is to justify the doctrine of choosing social tax policy guidelines, based on the current requirements of democratic transformation in Ukraine. The object of the research is labor relations in terms of market reform of the economy. The methods used of the research: methods of systematization and generalization methods; induction and deduction; interdisciplinary analogy. The hypothesis of the study was the assumption that bringing the salary into line with the cost of labor requires significant improvement of labor relations, the adoption of the new Labor Code in the context of market subjection of indus-

${ }^{1}$ Чернявська Євгенія Іванівна, д-р екон. наук, професор кафедри «Економіка та підприємництво», Східноукраїнський національний університет ім. В. Даля, м. Сєвєродонецьк, Україна.

Chernyavskaya Evgenia, Professor, Ph.D. in Economics, Professor of Economy and Entrepreneurship Department Volodymyr Dahl East Ukrainian National University, Severodonetsk, Ukraine.

ORCID ID: 0000-0002-6805-1141

e-mail: isoterika77@gmail.com

2 Овсчкіна Олена Андріївна, канд. екон. наук, доцент кафедри «Економіка та підприємництво», Східноукраїнський національний університет ім. В. Даля, м. Сєвєродонецьк, Україна.

Ovechkina Olena, Ph.D. in Economics, Assistant professor of Economy and Entrepreneurship Department Volodymyr Dahl East Ukrainian National University, Severodonetsk, Ukraine.

ORCID ID: 0000-0001-8822-7522

e-mail: economics@snu.edu.ua 
trial relations, which is part of the relationship with labor services. The statement of basic materials. It is substantiated that the labor market is a market of imperfect competition, with dominant positions of employers, because of the important role in regulating prices for labor services is played by the mechanism of collectivecontractual regulation of labor relations. In Ukraine, during market reforms, wages are underestimated. The originality and practical significance of the research. In the context of effective economic development, ensuring conditions for qualitative reproduction of human capital, achieving compromises in society requires a radical improvement of the nature of labor relations. This improvement involves the adoption of a number of legislative decisions. This is a legislative solution to the problem of subjection of industrial relations as a market form of economic development and addressing issues of effective employment. Subjection of industrial relations is a process of transformation of participants of economic activity into subjects of a modern market economy, which should be equal, have rights, social duties and mechanisms of protection. Conclusions of the research. In the organization of economic activity, the practice of economic activity, as well as in other spheres of society life should actively use the conceptual development of a positive and normative economic theory to create a partnership model of labor relations on a market basis. The biggest disadvantage of the market reform of the Ukrainian economy was the ignoring at the level of legislation of the conclusions and formulated requirements of economic theory, which caused a significant understatement of wages in relation to the cost of labor and caused the emergence of a number of negative phenomena.

Key words:

market economy, labor relations, theory of labor relations, labor force, labor potential, social partnership.

\section{ТРУДОВЫЕ ОТНОШЕНИЯ КАК ОБЪЕКТ РЫНОЧНОГО РЕФОРМИРОВАНИЯ ЭКОНОМИКИ}

Постановка проблемы. Статья посвящена анализу трудовых отношений в контексте стоимости рабочей силы в рыночной экономике. Целью статьи является обоснование доктрины выбора социальных ориентиров налоговой политики, исходя из современных требований демократических трансформации в Украине. Объектом исследования выступают трудовые отношения в ракурсе рыночного реформирования экономики. Методы, использованные в исследовании: методы систематизации и обобщения методы; индукции и дедукции; междисциплинарной аналогии. Гипотезой исследования стало предположение, что приведение уровня заработной платы в соответствие со стоимостью рабочей силы требует существенного усовершенствования трудовых отношений, принятие нового Трудового кодекса в контексте рыночной субъективации производственных отношений, составной частью которой выступают отношения по поводу услуг труда. Изложение основного материала. Обосновано, что рынок труда является рынком несовершенной конкуренции, с доминирующими позициями работодателей, из-за чего важную роль в регулировании цен на услуги труда играет механизм коллективно-договорного регулирования трудовых отношений. В Украине в течение рыночных реформ заработная плата является заниженной. Оригинальность и практическое значение исследования. В контексте эффективного экономического развития, обеспечение условий качественного воспроизводства человеческого капитала, достижения компромиссов в обществе нужно коренное усовершенствование характера трудовых отношений. Это усовершенствование предусматривает принятие ряда законодательных решений. Речь идет о законодательное решение проблемы субъективации производственных отношений как рыночной формы развития экономики и решения вопросов эффективной занятости. Субъективация производственных отношений - это процесс преобразования участников экономической деятельности в субъектах современной рыночной экономики, которые должны быть ровными, иметь права, социальные обязанности и механизмы защиты. Bbыводы исследования. В организации экономической деятельности, практике хозяйственной деятельности, как и в других сферах жизни социума должна активно использоваться концептуальные разработки позитивной и нормативной экономической теории по созданию партнерской модели трудовых отношений на рыночной основе. Наибольшим недостатком рыночного реформирования экономики Украины стало игнорирование на уровне законодательства выводов и сформулированных требований экономической теории, стало причиной существенного занижения заработной платы относительно стоимости рабочей силы и обусловило появление ряда негативных явлений.

Ключевые слова:

рыночная экономика, трудовые отношения, теория трудовых отношений, рабочая сила, трудовой потенциал, заработная плата, социальное партнерство.

Постановка проблеми. Базовими елементами економічної системи, як відомо, виступають трудові відносини і відносини власності на засоби виробництва. Характер трудових відносин або відносин з приводу послуг праці має відповідати потребам прогре- сивного розвитку продуктивних сил, 3 яких вагомішим фактором виступає праця, іiї носії. Саме по лінії трудових відносин в економічній системі в першу чергу проявляються протиріччя, що гальмують розвиток економічної системи, викликають соціальні конфлікти, 
деструкцій явища, актуалізують необхідність проведення в суспільстві соціальноекономічних реформ.

За формою з'єднання робочої сили із засобами виробництва соціалістична і капіталістична економічні системи багато в чому мають схожий характер, особливо те, що стосується форм найму на роботу. Реформування відносин 3 приводу послуг праці не стало таким чином окремим спеціалізованим напрямом ринкової перебудови. Уряд обмежився внесенням окремих змін в діючий з радянських часів КЗпП України, що практично не змінило систему працевлаштування й оплати праці та призвело до низки серйозних деструкцій, серед яких найбільш негативними виявилися: падіння престижу праці та іiі деіндустріалізація, зниження професіоналізму кадрів, посилення кризового стану людських ресурсів, наростання антагоністичного характеру трудових відносин та опортуністичної поведінки працівників тощо. Посилення негативних явищ в сфері праці та соціальнотрудових відносин провокує деструкційні процеси в інших сферах діяльності й підсистемах економіки, що свідчать про необхідність поглиблення наукового дослідження соціально- трудових відносин щодо їх удосконалення відповідно до законів ринкової економіки [1;2], що обумовлює актуальність теми та викладеного у статті матеріалу.

Аналіз останніх досліджень та публікацій. В економічній теорії приділяється значна увага вивченню законів і категорій розвитку праці. В працях Д. Богині, I. Есінової, А. Колота, В. Ланового, Є. Лібанової, В. Лича, Г. Осового, О. Уманського та інших дослідників набули системного відображення питання щодо сутності праці та трудових відносин, моделей та умов їх ефективного розвитку, ролі в соціально-економічному прогресі країни тощо [3; 4]. На підставі зроблених висновків вченими запропоновано напрями удосконалення трудових відносин, ефективного розвитку людського капіталу на сучасному етапі ринкових реформ $[1 ; 2] /$ Однак, наявність протилежних наукових підходів щодо розробки перспектив розвитку відносин $з$ послуг праці, слабке врахування досягнень теорії трудових відносин в законодавчий практиці України та наслідків реалізації реформ підприємницької діяльності зумовлюють необхідність подальшого розвитку теорії трудових відносин та визначення головних напрямів їх вдосконалення в умовах ри- нкових реалій української економіки.

Мета статті полягає у розгляді сутнісних рис трудових відносин, що формуються на ринкових засадах, та з'ясування найбільш негативних деформацій функціонування та розвитку відносин з послуг праці в Україні 3 визначенням основних напрямів їх удосконалення в контексті подальшого ринкового реформування економіки та розвитку підприємництва.

Виклад основного матеріалу дослідження. В ринковій економіці як типової форми суспільного виробництва всі фактори виробництва, процеси праці та їх результати, відтворювальні процеси здійснюються в товарній формі. Товар залишається економічною «клітинкою» ринкової економіки, що заснована на капіталістичній основі. Як відомо, всі товари мають дві властивості: споживчу вартість і вартість. Споживча вартість - це здатність товару задовольняти якусь потребу людини. Вона представлена у самій речі, уособлює собою сукупність матеріальних властивостей, які притаманні самому предмету. Споживча вартість як властивість товару виступає носієм вартості. У вартості, як відомо, відображається той факт, що вона $\epsilon$ формою суспільної праці, хоча виготовлення товару здійснюється приватним виробником, при цьому величина товару визначається суспільно необхідними витратами праці. Суспільно необхідні витрати складають основу вартості товарів, однак якою буде ціна, то це вирішує ринок. В залежності від співвідношення попиту і пропозиції ціна на товар може дорівнюватися до вартості товару, бути вище або нижче вартості товару. Рух ціни навколо вартості товару - це механізм дії закону вартості, механізм руху конкретних ринків, галузей виробництва, підприємств та ринкової економіки в цілому в умовах вільної конкуренції.

Викладені основи товарного виробництва класичної політичної економії доповнюються концепцією ринкових цін сучасної економічної теорії, за якою механізм встановлення ринкових цін представляється як: поперше, комплексний механізм руху ринкової економіки та відтворення факторів виробництва; по-друге, умова і результат суспільного поділу праці в усіх його формах. Вчені доходять спільного висновку про те, що ціноутворення в умовах вільної конкуренції $\epsilon$ найбільш сприятливим щодо розвитку відносин праці з позицій інтересів найманих робітни- 
ків. Монополізація економіки стримує розвиток поділу праці, й деформує принципи працевлаштування та оплати праці, через що в усіх розвинутих країнах світу існує антимонопольне законодавство та ефективно діючі антимонопольні комітети. I тут треба підкреслити, що дієвість антимонопольного законодавства забезпечується достатньо повною, чіткою специфікацією прав власності та незалежністю судової системи, яка саме призвана захищати ці права, в тому числі право власності на свою робочу силу й відповідну оплату послуг з надання праці.

В контексті сказаного, розробка й проведення ринкових реформ в Україні має спиратися на тому, що умовами виникнення та розвитку ринкової економіки виступають не ринкові ціни, а перш за все суспільний поділ праці та приватна власність на ресурси 3 необхідними інститутами іiі специфікації та захисту. Отже, концепція реформування економіки на ринкових засадах має забезпечити перед усім розвиток матеріально-технічної бази суспільного виробництва, поглиблення поділу праці, розширене відтворення основного виробничого фактора - робочої сили, іiі у ефективно діючий людський капітал.

Доречно зауважити, що незважаючи на теоретичне обгрунтування доцільності застосування моделі досконалої конкуренції, на ринки ресурсів, готової продукції, робочої сили, практично завжди були ринком недосконалої конкуренції, асиметричними, 3 домінуючими позиціями роботодавців та власників капіталу. 3 цього випливає те, що в разі відсутності специфікації прав власності на послуги праці (відсутності альтернативних капіталізму варіантів зайнятості, кодексів законів про працю або їх не тотожності законам діючої економічної системи), роботодавці завжди будуть економити на заробітній платі, кожного разу відроджуючи експлуатацію робочої сили як найбільш простого шляху вирішення проблеми прибутковості підприємств.

Зрозуміло, що наймані працівники об'єктивно не могли не реагувати на таке ставлення до праці. Відповідями роботодавцям стали страйки, революційні рухи, виникнення робітничих та комуністичних партій, політизація професійних спілок тощо. Під дією вказаних факторів протягом XIX століття були прийняті закони про обмеження праці дітей, неповнолітніх дівчат і жінок, про тривалість робочого дня, надання перших соціальних гарантій. Трудове право стало самостійною галуззю права, при цьому було визнано, що модель недосконалої конкуренції на ринку праці не дозволяла автоматично вирішувати проблеми повної зайнятості, розвитку трудового потенціалу, досягнення соціальної гармонії та ефективності ринкової економіки [2, с.15-16]. Поряд з ринком праці механізмом регулювання трудових відносин виступило колективно-договірне регулювання, в якому важливу роль стала відігравати держава.

Повертаючись до реалій української економіки, необхідно зауважити, що розробка дієвої програми реформаторських заходів на ринкових засадах мала починатися зі створення концепції побудови збалансованих, гармонічних трудових відносин, за якою у цивілізованій форм вирішуватимуться протиріччя економічних інтересів, найманих робітників, роботодавців, держави. В даній концепції мають також розроблятися такі питання щодо забезпечення розширеного відтворення робочої сили, як:

- формулювання вимог діючих економічних законів (перед усім законів відтворення, ринкових законів попиту і позиції тощо), яких не можна ігнорувати, плануючи заходи щодо розвитку відносин праці. Так, згідно принципу еквівалентного обміну, що діє в системі ринкових відносин, не можна за безцінь купувати робочу силу і тривалий час примусово змушувати іï ефективно працювати. Як найменше, недотримання цього принципу порушує не лише дію об'єктивних економічних законів, але й суперечить визнаним суспільством формальним нормам, правилам спілкування, іншими словами посилює конфліктність процесів об'єктивізації й суб'єктивізації економічних відносин, особливо у сфері праці;

- поглиблене визначення відповідно до реалій вітчизняних ринкових відносин сутності й змісту інституту колективних договорів між найманими працівниками і роботодавцями. У розв'язанні теоретичних і практичних проблем реформування соціально-трудових відносин саме переговори та укладання колективних договорів між найманими працівниками і роботодавцями мають усунути конфліктність означених вище процесів, відрегулювати низку питань щодо забезпечення партнерського характеру трудових відносин, подальшого розвитку праці та підвищення ефе- 
ктивності економічної діяльності як на рівні підприємств, так і економіки в цілому;

- дослідження питань ринку праці (купівлі-продажу робочої сили) в руслі розв'язання всіх проблем трудових відносин в сфері праці, перед усім проблеми підвищення технічної будови виробництва та економії живої праці з усіма її наслідками. Якщо світова економіка 3 середини XX століття вже двічі оновила свої базові технології, українські підприємства традиційних галузей залишаються в минулому. Вони використовують більше електроенергії, більш трудомісткі, потребують більше фінансового капіталу на випуск одиниці продукції, і ця продукція $є$ гіршої якості [4]. Закономірно постоюють питання, чи зможуть такі підприємства ефективно адаптуватися до ринкових умов EC?

В руслі основних теоретичних проблем реформування соціально-трудової сфери суспільних відносин особливої актуальності набувають також питання щодо змін в: організації виробництва і праці; забезпеченні продуктивної зайнятості; нормуванні та оплати праці; встановленні гарантій, компенсацій, пільг; участі трудового колективу у формуванні, розподілі та використанні прибутку підприємства (якщо це передбачено статусом); режимі роботи, тривалості робочого часу і відпочинку; умов та охорони праці тощо.

3 приводу сказаного слід наголосити, що на сьогодні в Україні прийнята низка законів щодо регулювання та укладання колективно-договірних відносин. Однак ефективність прийнятих законів замала, адже ними не усунути недоліки існуючого колективнодоговірного регулювання, перед усім існування заниженого понині рівня заробітної плати, що провокує негативні тенденції в економіці та сфері праці, до яких необхідно віднести наступне:

- обмеження платоспроможного попиту, звідси, зниження ємності ринку споживчих товарів, товарів довготривалого користування, що негативно позначається на фінансових можливостях розвитку підприємств II і I підрозділів суспільного виробництва, стані соціальної сфери, а також підприємництва в цілому;

- гальмування розвитку трудового потенціалу та фактично демотивація ефективної праці. Особливо негативний вплив дешевизна робочої сили має на престиж праці, що тягне за собою нову низку негативів. Не маючи реальної можливості придбання товарів та послуг, які позиціонують реклама, інші засоби інформації в якості кредо сучасного життя, значна частина населення надає перевагу зниженню рівня власних домагань, зменшуючи власні потреби. Це породжує трудову та суцільну соціальну пасивність, знецінення чесної і сумлінної праці, байдужість до суспільно-нагальної потреби підвищення кваліфікації, професіонального зростання тощо. На зміну активності приходить пасивність найманих робітників - найгірша форма опортуністичної поведінки власників робочої сили, що стає найсуттєвішим фактором загрози національній економічній безпеці країни;

- відтік робочої сили за кордон, що набув загрозливих розмірів. За останні 20 років з України виїхало від 7\% до $15 \%$ економічно активного населення. Це ті українці, що усвідомили й психологічно сприйняли вимоги ринкової економіки, мають внутрішній потенціал до змін, в тому числі і до міграційних процесів відповідно до запитів ринку праці. Своє майбутнє вони обгрунтовано пов'язують не 3 видатками держави, а з самостійно організованою працею. Певний відсоток тих, хто виїхав за кордон, вже залишився там назавжди, інша частина - продовжує працювати і має наміри повернутися в країну. За останні два роки збільшився відсоток тих, хто готовий виїхати з України. За даними соціологів, ця готовність зумовлена не лише новинами 3 фронту на Донбасі, але й реаліями буденного мирного життя [3].

Необхідно зауважити, що економічна наука постійно звертає увагу на невідповідність рівня заробітної плати умовам інноваційно-орієнтованої ринкової економіки. В наукових колах добре відома стаття академіка Лібанової Е.М. 3 символічною назвою «Кому вигідна дешева робоча сила», в якій показано, що досвід економічно розвинутих країн і ще більшою мірою країн, які здійснили економічний ривок у різні періоди XX століття - Японія, Корея, Німеччина, Ірландія, Чехія, Угорщина, Словенія, свідчить про вирішальне значення саме людського капіталу, високої якості робочої сили і мотивації ефективності дорогої праці [5]. Напроти, Україна дотримується характерної для азіатських країн економічної доктрини, яка спирається на принципи невисокої якості та низької вартості, дешевизни ресурсів. Нашій державі необхідно відійти від моделі економічного розви- 
тку 3 дешевими ресурсами, перед усім робочої сили, маючи для цього певні можливості, що підтверджується розрахунками фахівців Інституту економіки і прогнозування, які доводять, що при здійсненні цього процесу поступово, значного зростання цін не відбудеться [5]. Погоджуючись 3 даними висновками, ще раз слід наголосити, що розробка концепції побудови збалансованих, гармонічних трудових відносин стає вкрай актуальною, й, на наш погляд, може розпочатися 3 використання переваг західного варіанту умовного розподілу економічної теорії на позитивну і нормативну.

Як відомо, позитивна економічна теорія на рівні практиці вивчає економічні факти, процеси, закономірності тощо та 3'ясовує причини соціально-економічного стану, що склався. В контексті нормативної економічної теорії наголошується, що заробітна плата характеризується як ринкова форма вартості робочої сили й має виконувати всі функції, що їй притаманні в механізмі ринкової економіки. Без цього українська економіка не вийде 3 економічної кризи, не зможе подолати інволюційні процеси та перейти до розвитку за моделлю якісного зростання.

На відміну від позитивної нормативна економічна теорія описує, якою має бути система економічних відносин політика в контексті досягнення суспільних компромісів, забезпечення гармонії соціально-трудових відносин та соціально-економічного розвитку, відродження конкурентоспроможності на внутрішньому та світовому ринках. У вигляді комплексу інституціонально-економічних форм, норм, правил, механізмі, позитивна економічна теорія обгрунтовує коло обмежень та дозволів в певних моделях державної, колективної та індивідуальної поведінки, розробляє рекомендації щодо прийняття відповідних господарських рішень в практичній діяльності економічних суб' єктів [6].

Моделювання колективної поведінки (поведінки підприємств) $€$ вкрай важливим питання нормативної й позивної економічної теорії, адже безпосередньо стосується реалізації економічних індивідуальних й державних інтересів. Як відомо, капіталістичне підприємство - це кооперація праці, яка саме є основою синергетичного ефекту, народження безпосередньо суспільної продуктивності праці. Капіталістична кооперація праці надає можливості оплачувати робочу силу за їі вартістю та задовольняти інтереси підприємців в формі прибутку, що є формою синергетичного ефекту або безпосередньо суспільної продуктивності праці та впроваджувати інституціональну модель соціального партнерства. Укладання та регулювання трудових відносин в рамках соціального партнерства як суспільного інституту дозволяє конфліктність, антагонізм, пасивність у відносинах між найманими робітниками і роботодавцями перевести в русло ефективного співробітництва та компромісів в суспільстві. Безперечно, питання заробітної плати в рамках колективних угод і договорів мають вирішуватися в контексті інтересів всіх учасників економічної діяльності. Для цього має бути використана така інституціональна форма, як соціальне партнерство.

Сьогодні соціальне партнерство - інститут трудових відносин - за параметрами розвинутих країн дозволяє ефективно, в контексті соціально-економічного прогресу країни вирішити проблему перетворення заробітної плати в сучасну ринкову форму відтворення людського капіталу, розвитку трудового потенціалу країни, регіонів, підприємств. Крім того, соціальне партнерство має стати такою інституціонально-економічною формою, через яку урядові та підприємницькі структури були б зацікавлені в співпраці та врахуванні рекомендацій економічної науки, а влада в суспільстві організувалась за принципами інклюзивних політичних та економічних інститутів [7].

Отже, в контексті ефективного економічного розвитку, забезпечення умов якісного відтворення людського капіталу, досягнення компромісів у суспільстві потрібно докорінне удосконалення характеру трудових відносин. Суб'єктивація виробничих відносин - це процес перетворення учасників економічної діяльності в суб'єктів сучасної ринкової економіки, які повинні бути рівними, мати права, соціальні обов'язки та механізми захисту.

Для цього перед усім необхідний перегляд законодавчих умов організації економічної діяльності в формі підприємств як приватних (одноосібних), так і акціонерних товариств, що безпосередньо вплине на зміни у соціальній свідомості людей, їх ставлення до бізнесу, особливо великому. Так, майже після п'ятнадцятирічного розвитку ринкової економіки в Україні соціальні опитування показують, що приватновласницькі вподобання населення оцінюються експертами як дуже 
скромні: якщо мати (гіпотетично) у власності мале підприємство хотіли б близько 20\% українців, то середнє або велике підприємство - лише $8,5 \%$, у той час як $60,9 \%$ населення не хотіли б мати нічого 3 перерахованого, окрім пристойної заробітної плати [8, с. 137]. Якщо згадати, наприклад, про вади в розрахунках рівня податків та умов їх сплати, про перевірки бізнесу різними державними організаціями та дорожнечу й обмеженість фінансових ресурсів, стає очевидним, що складності розвитку підприємництва лежать саме в площині законодавства. При цьому, мабуть найбільш складним питанням залишається проблема суб' єктивації держави як учасника економічної діяльності.

В аспекті сказаного слід зауважити, що в першу чергу необхідно провести розмежування понять держави 3 відповідними структурами як представника соціуму і держави як сукупності державних органів, вищих посад, які обіймають обрані громадяни. Формальні інститути діяльності державних службовців в кадровій політиці, з одного боку, суттєво обмежують вплив таких чинників як родинність, корупція, а, з іншого боку, орієнтують на працевлаштування в державних органах влади дійсних професіоналів.

Особливо актуальним питанням в Україні є проблема суб'єктивації найманих працівників в контексті захисту їх інтересів профспілками. В західних країнах професійна спілка це організація найманих робітників, сформованих $з$ метою покращення їх доходів та умов праці на підставі колективних торгів, переговорів 3 роботодавцем або організаціями роботодавця. В Україні профспілки - це не професійні, а громадські організації, що об'єднуюють громадян, пов'язаних спільними інтересами за родом їх професійної (трудової) діяльності. За Законом України «Про професійні спілки, їх права та гарантії діяльності» членами профспілок можуть бути і роботодавці, проте вони не можуть обиратися в керівні органи профспілки будь-якого рівня [9]. Не зважаючи на це, реальна сила роботодавців в профспілках на підприємствах, на яких до того ж знаходяться і офіси профспілок, надзвичайно велика. Профспілки в дійсності є агентами, захисниками інтересів роботодавців, а не найманих робітників. Це одна із головних причин того, що так зване ринкове реформування економіки здійснювалось і здійснюється 3 великими соціальними втратами: значним скороченням робочих місць, зниженням реаль- ної заробітної плати, життєвого рівня, чисельності населення і трудових ресурсів, падінням престижу праці і робітничих професій тощо.

В інституціональному плані розв'язання питання щодо створення профспілкової організації, яка захищатиме інтереси найманих працівників, достатньо проста. Необхідно внести відповідні зміни в законодавство про профспілки, позбавити членства в профспілках роботодавців та винести офіси профспілок за межі підприємств, в яких укладаються колективні угоди між найманими працівниками і роботодавцями $[10$, с. 32]. Удосконалення характеру трудових відносин потребує також їх загального правового регулювання, прийняття нового Трудового кодексу, розробка концепції якого має будуватись на соціально-партнерській формі регулювання трудових відносин, причому в контексті узгодженості інтересів найманих працівників, роботодавців і держави, як соціуму. В цьому плані необхідно в першу чергу розробити та ухвалити Закон України «Про соціальне партнерство», прийняти нову редакцію Закону України «Про колективні договори $\infty$ і угоди». Забезпечення рівноваги прав працівників і роботодавців, балансу їх інтересів та інтересів держави є тим критерієм, якому мають відповідати всі нормативні правові акти, що регулюють трудові відносини, i, в першу чергу сам Трудовий кодекс України.

Висновки та перспективи подальших досліджень. Ефективний розвиток економіки в умовах ринкової організації виробництва пов'язаний 3 використанням всіх товарних форм відповідно до їх, товарного змісту. Сутність і явище, форма і зміст, як правило, не співпадають. За ринковими формами можуть скриватися нееквівалентні принципи взаємовідносин, навіть зовсім не товарний зміст. 3 цього приводу слід сказати, що в організації економічної діяльності, практиці господарської діяльності, як і в інших сферах життя соціуму має активно використовуватися концептуальні розробки позитивної та нормативної економічної теорії щодо створення партнерської моделі трудових відносин на ринковій основі.

Найбільшою вадою ринкового реформування економіки України стало ігнорування на рівні законодавства висновків й сформульованих вимог економічної теорії, що стало причиною суттєвого заниження заробітної плати відносно вартості робочої сили й обумовило появу низки негативних явищ, серед яких особливо деструктивними є: об- 
меження платоспроможного попиту, гальмування розвитку трудового потенціалу, демотивація ефективної праці та падіння їі престижу, зростання міграції висококваліфікованої робочої сили тощо. Приведення заробітної плати у відповідність до вартості робочої сили можливо за умов суттєвого, кардинального реформування трудових відносин, прийняття нового Трудового кодексу в контексті суб'єктивації всієї системи виробничих відносин, до складу якої входять і трудові відносини.

\section{Література}

1. Чернявська $C$. I. Щодо узгодженості та гармонізації інтересів учасників економічної діяльності / Є. І. Чернявська // Вісник Східноукраїнського національного університету імені Володимира Даля. - №6 (230). - Луганськ: СНУ ім. В Даля, 2016. - С. 218-223.

2. Чернявська $C$. I. Реструктуризація підприємства в умовах трансформаційної економіки : монографія / С. І. Чернявська. - Луганськ : Вид-во СНУ ім. В.Даля, 2004. - 264 с.

3. Радчук О. У пастці економічної безвиході: нові ризики трудової міграції для України. / О. Радчук. [Електронний ресурс]. - Режим доступу: https://www.slovoidilo.ua/

4. Лановой В. Правительство временных / В. Лановой. [Электронный ресурс]. - Режим доступа: https://www.epravda.com.ua/public/2015

5. Лібанова $E$. Кому вигідна дешева робоча сила / Е. Лібанова. [Електронний ресурс]. - Режим доступу: https://dt.ua/econom/

6. Аджемоглу Дарон Почему одни страны богатые, а другие бедные. Происхождение власти, процветания и нищеты / Дарон Аджелоглу, Джеймс А. Робинсон; пер. с англ. Д. Литвинова, П. Миронова, С. Сановича. - М.: Издательство АСТ, 2016. - 693 с.

7. Філіпішин I. B. Організаційноекономічний механізм управління ресурсним потенціалом будівельних підприємств: монографія / I. В. Філіпішин, О. А. Овєчкіна. - Сєвєродонецьк: вид-во СНУ ім. В. Даля, 2017. - 148 c.

\section{Стаття надійшла}

до редакції : 02.09.2018 p.
8. Резнік C. В. Соціальна легітимність приватної власності та ментальність українців очима експертів / С. В. Резнік // Український соціум. 2006. - № 5. - C. 131-141.

9. Закон України «Про професійні спілки, їх права та гарантії діяльності». [Електронний pecypc]. - Режим доступу: http://ukrelectrop.org.

10. Чернявська $C$. I. Управління розвитком трудового потенціалу: інституціональні аспекти / Є. I. Чернявська // Часопис економічних реформ. - 2017. - №3(27). - C. 29-34

\section{References}

1. Chernyavska, E. I. (2016). Concerning the coherence and harmonization of the interests of economic operators. Bulletin of the Volodymyr Dahl East-Ukrainian National University, 6(230). Lugansk: SNU V. Dahl, 218-223.

2. Chernyavska ,E. I. (2004). Restructuring of an enterprise in a transformational economy: monograph. Lugansk: SNU V. Dahl, 264.

3. Radchuk, $O$. In the trap of economic hopelessness: new risks of labor migration for Ukraine. Retrieved from: https://www.slovoidilo.ua

4. Lanovoy, B. (2015). Government temporary. Retrieved from: https://www.epravda.com.

5. Libanova, E. To whom is cheap cheap labor. Retrieved from: https://dt.ua/economics

6. Ademoglu, Daron \& Robinson, James A. (2016). Why some countries are rich, and others are poor. The Origin of Power, Prosperity and Poverty. Moscow: AST Publishing House, 693.

7. Filiskishin, I. V. \& Ovechkina, O. A. (2017). Organizational and Economic Mechanism for Managing the Resource Potential of Construction Enterprises: Monograph. Severodonetsk: SNU V. Dahl, 148.

8. Reznik, S. V. (2006). B. Social legitimacy of private property and mentality of Ukrainians in the eyes of experts. Ukrainian Society, 5, 131-141.

9. Law of Ukraine "On Trade Unions, Their Rights and Guarantees of Activity". Retrieved from: http://ukrelectroprofspilka.org.ua.

10. Chernyavska, E. I. (2017). Management of labor potential development: institutional aspects. Time description of Economic Reforms, 3(27), 29-34.

\section{Стаття прийнята}

до друку: 20.11.2018 p.

\section{Бібліографічний опис для цитування :}

Чернявська Є. І. Трудові відносини як об'єкт ринкового реформування економіки / Є. I. Чернявська, О. А. Овєчкіна // Часопис економічних реформ. - 2018. - № 4 (32). - С. 73-80. 